Acta vet. scand. 1971, 12, $489-495$.

From the Department of Animal Husbandry and Genetics and the Department of Physiology, Veterinary College of Norway, Oslo.

\title{
FREE GLYCEROL IN THE PLASMA OF COWS
}

By

Knut Flatlandsmo

Nonesterified fatty acids (NEFA) evidently reflect the metabolism of fat in the organism. This has been confirmed for several types of animals. Kronfeld (1965) in cows found increased concentrations in cases of spontaneous ketosis, starvation, and abomasal displacement. He further noticed a diurnal variation of plasma NEFA concentration with a depression following feeding.

Free glycerol is present in small amounts in the blood of various animal species (Shafrir \& Gorin 1963, Britton 1962, Havel \& Carlson 1963). Several reports indicate that the concentration of free glycerol tends to follow that of NEFA. In children this is confirmed by Nitzan et al. (1968), in man by Shafrir \& Gorin, and in sheep by Bergman (1968), and Aulie et al. (1971).

The principal source of free glycerol seems to be adipose tissue (Borchgrevink \& Havel 1963). They suggest, however, that small amounts of glycerol may be formed elsewhere.

The free glycerol concentration is determined by the balance between the rate of production and utilization. Himms-Hagen (1968) reports that the utilization of glycerol may entirely depend on its concentration, and blood changes depend on the rate of production. Winkler et al. (1969) using dogs in their experiments, have confirmed these results for concentrations within 
the physiological range. Robinson \& Newsholme (1969) suggest that the metabolism of glycerol within the tissue evidently plays an important role.

Different hormones and drugs interfer with glycerol metabolism. Injection of epinephrine to man induces elevation of serum glycerol, while oral glucose administration causes a decrease (Shafrir \& Gorin). Administration to rabbits of a fatmobilizing substance from pig pituitary gland, is followed by increased serum glycerol (Sim et al. 1964). Tests with rats indicate the importance of insulin in the regulation of glycerokinase (Kampf et al. 1970). Children with starvation ketosis exhibit increased levels of NEFA and plasma glycerol, while plasma insulin is decreased (Nitzan et al.).

The relation of glycerol to blood sugar has been reported in several papers. In fasted rats and sheep, $40 \%$ or more of glucose turnover originates from glycerol (Bergman et al. 1968, Nikkilä $\&$ Ojala 1963). Turnover time of free glycerol in sheep is determined to $15-18 \mathrm{~min}$. This corresponds to a half life of $11 \mathrm{~min}$. The turnover rate increases in ketosis and hunger (Bergman). In dogs Havel \& Carlson estimated fractional turnover rate to $0.04-0.09 / \mathrm{min}$. This corresponds to a turnover time of $11-25$ min. In human serum free glycerol hardly constitutes more than $10 \%$ of total glycerol (Eggstein 1966).

The removal of glycerol from the blood is mainly caused by the liver (Borchgrevink \& Havel, Larsen 1963). This is due to a high concentration of glycerokinase in the organ. Small amounts are removed by the kidney. The same enzyme is also found in the gut (Clark \& Hübscher 1962), rat heart and adipose tissue (Robinson \& Newsholme 1967).

The bovine mammary gland can utilize glycerol for biosynthesis of various lipids. The presence of glycerokinase in the mammary gland has been demonstrated for several animal species (Kinsella 1968, McBride \& Korn 1964, Carlson et al. 1964).

Since no studies on free glycerol in plasma of cows seem to have been reported, it was found of interest to relate this parameter of fat mobilization to pregnancy and lactation in dairy cows $^{*}$. The present paper presents data from animals on 2 farms with different milk yields.

* In Acta vet. scand. 1971, 12, 230-242, an article concerning some of the same problems is published by Bo Pehrson. 


\section{MATERIAL AND METHODS}

Twenty-one cows of the Norwegian Red Cattle breed were used. Fifteen animals were herded at the research farm Wöyen, the other 6 at the research farm Hellerud. The mean yearly milk yield of the cows from Wöyen were $4,045 \mathrm{~kg}$ with $4.3 \%$ fat, (174 kg milk fat) while the corresponding data from Hellerud were $5,694 \mathrm{~kg}$ with $4.2 \%$ fat $(239 \mathrm{~kg}$ milk fat). Six of the cows at Wöyen were from an experiment with D-L methionine supplementation, $10 \mathrm{~g}$ per cow per day. The amino acid had been coated to avoid microbial degradation in the rumen. The supplement was given from 1 month before expected calving, and ceased at 90 days post partum. The feed consisted on both farms of grass silage, root crops, alkali-treated straw, and concentrates.

Blood samples were collected by venipuncture, in heparine test tubes. After centrifugation plasma was stored at $-20^{\circ} \mathrm{C}$ until time of analysis. All samples from Hellerud were collected in the morning before feeding. With a few exceptions, the same was true with the samples from Wöyen. The experimental work was carried out during indoor feeding.

\section{Analytical procedure}

Glycerol was determined enzymatically according to a slight modification of the method described by Eggstein \& Kreutz (1966), Eggstein (1966), and Schmidt \& von Dahl (1968). For each mol of glycerol phosphorylated, $1 \mathrm{~mol}$ of $\mathrm{NAD}+$ is formed. The amount of NAD was determined by a Zeitz spectrophotometer at $334 \mathrm{~nm}$. The temperature was constant, $25^{\circ} \mathrm{C}$, and the extinction was read against a blind of diluted picric acid.

The change of extinction was recorded continuously. This was found necessary, due to unspecific influence on NADH. The same phenomenon is seen by analysing plasma from sheep (Aulie et al. 1971). Glycerokinase was always added after 21 min., and the reaction was followed until $41 \mathrm{~min}$. Twenty samples were analysed without adding glycerokinase. Optical changes in the interval 15-20 min. (x) and 21-41 min. (y) were calculated by means of the regression equation $y=0.861 x+6.96$. A blind was substracted for each sample to get the true extinction caused by glycerokinase. Ten samples from 2 different stock solutions of glycerol were analysed with a water blind. By means of these standards, a factor was calculated by which the extinction values 
were converted to glycerol values. Duplicated analyses of 27 samples gave a coefficient of variation of $13 \%$.

\section{RESULTS AND DISCUSSION}

The results are given in Table 1 . The pre partum interval includes samples collected until 2 months before delivery. The other intervals indicate variations related to partus and lactation. The majority of the samples (122 out of 173) originated from Wöyen, 43 from cows receiving an extra supplement of D-L-methionine. Since no significant difference in plasma glycerol could be detected between supplemented and non-supplemented animals, and since samples collected in the morning showed no significant difference from those taken at other times of the day, all samples from Wöyen are treated together.

The levels of free glycerol in plasma of cows found in the present investigation, 27-110 $\mu \mathrm{mol} / \mathrm{l}$, seem to be comparable with values reported for other species: $120 \mu \mathrm{mol} / 1$ in human beings (Eggstein 1966), 26-85 $\mu \mathrm{mol} / \mathrm{l}$ in dogs (Havel \& Carlson 1963), 50-64 $\mu \mathrm{mol} / \mathrm{l}$ in rats (Kampf et al. 1970), and 39-119 $\mu \mathrm{mol} / 1$ in sheep (Aulie et al. 1971).

A significant increase of free glycerol was observed at the time of partus. This is similar to what has been observed in

T a b l e 1. Plasma concentration $(\bar{x} \pm s)$ of free glycerol ( $\mu \mathrm{mol} / \mathrm{l})$ at different stages of lactation.

\begin{tabular}{|c|c|c|c|c|c|c|}
\hline & \multicolumn{2}{|c|}{$\begin{array}{l}\text { Pre partum } \\
<60 \text { days }\end{array}$} & \multicolumn{2}{|c|}{$\begin{array}{c}\text { Post partum } \\
0-2 \text { days }\end{array}$} & \multicolumn{2}{|c|}{$\begin{array}{l}\text { Post partum } \\
\text { 3-45 days }\end{array}$} \\
\hline & $\begin{array}{c}\text { no. of } \\
\text { samples }\end{array}$ & $\begin{array}{c}\text { free } \\
\text { glycerol }\end{array}$ & $\begin{array}{c}\text { no. of } \\
\text { samples }\end{array}$ & $\begin{array}{c}\text { free } \\
\text { glycerol }\end{array}$ & $\begin{array}{l}\text { no. of } \\
\text { samples }\end{array}$ & $\begin{array}{c}\text { free } \\
\text { glycerol }\end{array}$ \\
\hline \multirow{4}{*}{$\begin{array}{l}\text { Wöyen } \\
\text { Hellerud }\end{array}$} & 28 & $37 \pm 14$ & 10 & $110 \pm 42^{\star \star \star}$ & 66 & $51 \pm 19^{\star \star \star}$ \\
\hline & 13 & $45 \pm 11$ & & & 29 & $82 \pm 21^{* \star *}$ \\
\hline & \multicolumn{2}{|c|}{$\begin{array}{l}\text { Post partum } \\
46-90 \text { days }\end{array}$} & \multicolumn{2}{|c|}{$\begin{array}{l}\text { Post partum } \\
>91 \text { days }\end{array}$} & \multirow[b]{2}{*}{$\begin{array}{l}\text { No. of } \\
\text { cows }\end{array}$} & \multirow[b]{2}{*}{$\begin{array}{l}\text { Total no. } \\
\text { of samples }\end{array}$} \\
\hline & $\begin{array}{c}\text { no. of } \\
\text { samples }\end{array}$ & $\begin{array}{c}\text { free } \\
\text { glycerol }\end{array}$ & $\begin{array}{c}\text { no. of } \\
\text { samples }\end{array}$ & $\begin{array}{c}\text { free } \\
\text { glycerol }\end{array}$ & & \\
\hline Wöyen & 11 & $48 \pm 19$ & 7 & $27 \pm 9^{\star}$ & 21 & 122 \\
\hline Hellerud & 9 & $52 \pm 22^{\star \star}$ & & & 6 & 51 \\
\hline
\end{tabular}

${ }^{*}(\mathrm{P}<0.05),{ }^{\star *}(\mathrm{P}<0.01),{ }^{\star \star *}(\mathrm{P}<0.001)$ indicate significance of change from the previous period. 
human beings by Sabata et al. (1968). In addition these authors recorded a considerable increase of NEFA and ketone bodies. The rise was supported to be due to the energy demand.

As shown in the table, values from Hellerud were significantly higher in the 3-45 days interval than those from Wöyen $(\mathrm{P}<0.001)$. Since the feeding and housing conditions were rather similar at both places, the difference in milk yield may be of importance. Mean yield for the cows at Hellerud was in the actual period $29.4 \mathrm{~kg}, 4 \%$ fat (9 samples), while the corresponding data at Wöyen were $21.1 \mathrm{~kg}, 4 \%$ (12 samples). On considering the 2 farms together, a close positive correlation was found between milk yield and free glycerol in plasma ( $\mathrm{P}<$ 0.001 ).

The samples collected more than 91 days post partum, were at a lower level than the corresponding values pre partum, possibly expressing an increased fat mobilization before partus.

A far more marked increase was found in sheep by Aulie et al. recording a duplication of the values during the last 2 months of gestation.

In a recent report (Varman \& Schultz 1968) several blood lipids of cows were studied. Samples were examined in late lactation, in the dry, and in the early lactation period. The amount of NEFA was at the lowest level in late lactation, increasing to a peak early in the new lactation. This agrees well with the present results for free glycerol. The authors further observed that the amount of triglycerides was highest in the dry period with a considerable fall to the early lactation. Levels of blood sugar, ketone bodies, acetate, and free cholesterol were higher during early lactation than during the dry period.

\section{REFERENCES}

Aulie, A., H. N. Astrup, J. J. Nedkvitne \& W. Velle: Serum non-esterified fatty acids and plasma glycerol as indicators of fat mobilization in pregnant sheep subjected to cold stress. Acta vet. scand. 1971, 12, 496-503.

Bergman, E. N.: Glycerol turnover in the nonpregnant and ketotic pregnant sheep. Amer. J. Physiol. 1968, 215, 865-873.

Bergman, E. N., D. J. Starr \& S. S. Reulein jr.: Glycerol metabolism and gluconeogenesis in the normal and hypoglycemic ketotic sheep. Amer. J. Physiol. 1968, 215, 874-880.

Borchgrevink, C. F. \& R. J. Havel: Transport of glycerol in human blood. Proc. Soc. exp. Biol. (N.Y.) 1963, 113, 946-949. 
Britton, $H$. G.: Some non-reducing carbohydrates in animal tissues and fluids. Biochem. J. 1962, 85, 402-407.

Carlson, D. M., D. Crindler \& R. G. Hansen: Metabolism of glycerol by the mammary gland. Proc. Soc. exp. Biol. (N.Y.) 1964, 117, $894-895$.

Clark, B. \& G. Hübscher: Glycerokinase in mucosa of the small intestine of the cat. Nature (Lond.) 1962, 195, 599.

Eggstein, M.: Eine neue Bestimmung der Neutralfette im Blutserum und Gewebe. II. Zuverlässigkeit der Metode, andere Neutralfettbestimmungen, Normalwerte für Triglyceride und Glycerin im menschlischen Blut. (A new method for the determination of neutral fats in blood serum and tissues. II. Reliability of the method, other methods for determination of neutral fats, and normal values of triglyceride and glycerol in human blood). Klin. Wschr. 1966, 44, 267-273.

Eggstein, M. \& F. H. Kreutz: Eine neue Bestimmung der Neutralfette im Blutserum und Gewebe. I. Prinzip, Durchführung und Besprechung der Metode. (A new method for the determination of neutral fats in blood serum and tissues. I. Principle, performance and discussion of the method). Klin. Wschr. 1966, 44, 262-267.

Havel, R. J. \& L. A. Carlson: Comparative turnover rates of free fatty acids and glycerol in blood of dogs under various conditions. Life Sci. 1963, 2, 651--658.

Himms-Hagen, Jean: Glycerol metabolism in rabbits. Canad. J. Biochem. 1968, 46, 1107-1114.

Kampf, S. C., H. J. Seitz \& W. Tarnowski: Hormonal and metabolic control of rat liver glycerol kinase activity. Hoppe-Seylers Z. physiol. Chem. 1970, 351, 32-40.

Kinsella, J. E.: The incorporation of $\left({ }^{14} \mathrm{C}_{3}\right)$ glycerol into lipids by dispersed bovine mammary cells. Biochim. biophys. Acta 1968, $164,540-549$.

Kronfeld, D. S.: Plasma non-esterified fatty acid concentrations in the dairy cow: Responses to nutritional and hormonal stimuli, and significance in ketosis. Vet. Rec. 1965, 77, 30-35.

Larsen, J. A.: Elimination of glycerol as a measure of the hepatic blood flow in the cat. Acta physiol. scand. 1963, 57, 224-234.

McBride, O. W. \& E. D. Korn: Presence of glycerokinase in guinea pig mammary gland and the incorporation of glycerol into glycerides. J. Lipid Res. 1964, 5, 442-447.

Nikkilä, E. A. \& K. Ojala: Glycerol as an endogenous precursor of body glucose in the rat. Ann. Med. exp. Fenn. 1963, 41, 478-484.

Nitzan, M., A. Kowadlo-Silbergeld, M. Doron \& Z. Laron: Metabolic substrates and hormones during starvation ketosis in children. Amer. J. clin. Nutr. 1968, 21, $1268-1273$.

Robinson, Janice \& E. A. Newsholme: Glycerol kinase activities in rat heart and adipose tissue. Biochem. J. 1967, 104, 2c-4c. 
Robinson, Janice \& E. A. Newsholme: Some properties of hepatic glycerol kinase and their relation to the control of glycerol utilization. Biochem. J. 1969, 112, 455-464.

Sabata, V., H. Wolf \& S. Lausmann: The role of free fatty acids, glycerol, ketone bodies and glucose in the energy metabolism of the mother and fetus during delivery. Biol. Neonat. (Basel) 1968, $13,7-17$.

Schmidt, F. H. \& K. von Dahl: Zur Metode der enzymatischen Neutralfett-Bestimmung in biologischem Material. (Method for enzymic neutral fat determination in biological material). Z. klin. Chem. $1968,6,156$ - 159 .

Shafrir, E. \& E. Gorin: Release of glycerol in conditions of fat mobilization and deposition. Metabolism 1963, 12, 580-587.

Sim, A. W., J. W. De Vries \& J. E. Vincent: Concentrations of glycerol and non-esterified fatty acids in plasma during fat mobilization. Biochem. J. 1964, 92, 590-593.

Varman, P. N.\& L. H. Schultz: Blood lipids of cows at different stages of lactation. J. Dairy Sci. 1968, 51, 1971-1974.

Winkler, B., R. Steele \& N. Altszuler: Relationship of glycerol uptake to plasma glycerol concentration in the normal dog. Amer. J. Physiol. 1969, 216, 191-196.

\section{SUMMARY}

A survey is given on glycerol and its metabolism in the organism. Free glycerol in plasma was determined in 173 samples from 21 cows at 2 different farms. The highest concentration $110 \pm 42 \mu \mathrm{mol} / \mathrm{l}$ was observed in the interval $0-2$ days post partum. During the $3-45$ days post partum interval, a significant difference was observed between the 2 farms $(\mathrm{P}<0.001)$, with the highest values corresponding to the highest milk yields. The values found in cows correspond with levels previously reported for other species.

\section{SAMMENDRAG \\ Fritt glycerol i plasma hos kuer.}

Det er gitt en oversikt over glycerol og dets omsetning i organismen. Fritt glycerol i plasma ble bestemt i 173 pröver fra to forskjellige besetninger. Höyeste konsentrasjon $110 \pm 42 \mu \mathrm{mol} / 1$ ble funnet $\mathrm{i}$ intervallet $0-2$ dager etter kalving. I tidsrommet 3-45 dager etter kalving lå verdiene $\mathrm{i}$ den ene besetningen signifikant höyere enn $\mathrm{i}$ den andre $(P<0,001)$, og var korrelert med ytelsen. Verdiene som er funnet hos ku samsvarer med det som er funnet hos andre dyrearter. 